\title{
PERAN KELEMBAGAAN DALAM PENGEMBANGAN AGRIBISNIS MENDONG
}

\section{INSTITUTIONAL ROLE IN THE DEVELOPMENT OF MENDONG AGRIBUSINESS}

\author{
Tenten Tedjaningsih*, Suyudi, Hendar Nuryaman \\ Fakultas Pertanian, Universitas Siliwangi \\ *Email: tenten_ks@yahoo.co.id \\ (Diterima 15-02-2018; Disetujui 30-04-2018)
}

\begin{abstract}
ABSTRAK
Keberhasilan usahatani yang dilaksanakan tidak akan terlepas dari peran kelembagaan agribisnis. Apabila peran tersebut belum optimal maka pengembangan agribisnis komoditas akan terhambat. Penelitian ini bertujuan untuk mengetahui kepuasan petani terhadap kinerja kelembagaan agribisnis mendong. Penelitian dilaksanakan dengan menggunakan metode survei di Kecamatan Manonjaya, Kabupaten Tasikmalaya. Sampel yang digunakan sebanyak 25 orang petani mendong, pengambilan sampel menggunakan simple random sampling. Untuk mengetahui kinerja kelembagaan agribisnis digunakan Importance Performance Analysis (IPA), sedangkan untuk melihat kepuasan petani terhadap kinerja kelembagaan tersebut menggunakan Consumer Satisfaction Index (CSI). Hasil penelitian menunjukkan untuk kinerja kelembagaan agribisnis bahwa petani merasa puas dengan kios sarana produksi, pedagang pengumpul/bandar, pengrajin, kelompoktani, penyuluh dan perguruan tinggi yang cukup baik kinerjanya dalam menjalankan fungsi kelembagaan agribisnis pada usahatani mendong. Prioritas peningkatan fungsi kelembagaan terletak pada keberadaan koperasi, persyaratan pembelian mendong, harga jual mendong, kelompoktani sebagai unit produksi dan penyedia sarana produksi serta pelatihan oleh lembaga informasi dan teknologi. Sedangkan untuk kinerja kelembagaan menunjukkan bahwa kelembagaan agribisnis mendong masih perlu ditingkatkan lagi agar mampu menghadapi tantangan persaingan dengan penguatan kemandirian petani melalui peningkatan fungsi kelompoktani sebagai unit produksi dan pengadaan sarana produksi sehingga ada peningkatan nilai tambah dan nilai tukar dari kegiatan usahataninya dengan tidak terlepas dari adanya pelatihan penerapan inovasi teknologi dari lembaga terkait.
\end{abstract}

Kata kunci: Kelembagaan, Agribisnis, Kepentingan, Kinerja, Kepuasan

\section{ABSTRACT}

The success of farming implemented will not be separated from institutional role of agribusiness. If the role is not yet optimal then commodity agribusiness development will be hampered. This study aims to determine the satisfaction of farmers on the institutional performance of agribusiness mendong. The research was conducted by using survey method in Manonjaya Sub district, Tasikmalaya Regency. The sample used is 25 farmers mendong, sampling using simple random sampling. To know the institutional performance of agribusiness used Importance Performance Analysis (IPA), while to see farmer satisfaction on institutional performance use Consumer Satisfaction Index (CSI). The result of the research shows that for the agribusiness institution performance, the farmers are satisfied with the kiosks of production facilities, collectors / dealers, artisans, farmers, 
extensionists and universities that perform well in performing the institutional function of agribusiness in Mendong farming. Priority to improve the institutional function lies in the existence of cooperatives, purchase requirements mendong, selling prices mendong, farmers group as a production unit and provider of production facilities and training by information and technology institutions. As for institutional performance shows that institutional agribusiness mendong still need to be improved again in order to be able to face challenge of competition with strengthening of farmer independence through improvement of function farmers group as production unit and procurement of production means so that there is increase of added value and exchange rate from its farming activity by not apart from training application of technological innovation from related institutions.

Keywords: Institutional, Agribusiness, Interest, Performance, Satisfaction

\section{PENDAHULUAN}

Sektor agribisnis merupakan sektor ekonomi terbesar dan terpenting dalam perekonomian nasional Indonesia, sektor agribisnis menyerap lebih dari 75 persen angkatan kerja nasional termasuk didalamnya 21,3 juta unit usaha skala kecil berupa usaha rumah tangga pertanian. Apabila seluruh rumah tangga diperhitungkan maka sekitar 80 persen dari penduduk nasional menggantungkan hidupnya pada sektor agribisnis (Saragih, 2010).

Keberhasilan pengembangan suatu komoditas tidak hanya dipengaruhi oleh budidaya yang dilakukan oleh petani tetapi juga di luar budidaya baik pengadaan sarana produksi, penanganan pasca panen, pemasaran maupun jasa penunjang untuk kelancaran kegiatan tersebut, yang membentuk suatu sistem dan disebut dengan agribisnis.
Mengingat pada kenyataannya bahwa pembangunan pertanian terutama digerakkan oleh para petani dengan skala usaha kecil, dengan kemampuan modal serta penyerapan teknologi yang masih rendah, maka upaya menempatkan sektor pertanian sebagai poros penggerak pembangunan ekonomi harus mengutamakan peningkatan sumberdaya, sehingga pembangunan pertanian dan perdesaan yang ideal adalah terbentuk karena adanya partisipasi dari masyarakat desa (subjek) sebagai sebagai sasaran utama.

Pembangunan ekonomi perdesaan merupakan usaha meningkatkan taraf hidup masyarakat perdesaan yang dapat dicerminkan dengan meningkatnya pendapatan orang-orang sedaerah yang mempunyai kebutuhan yang sama sehingga akan menaikkan tingkat kehidupan bersama sehingga masyarakat tersebut menjadi lebih baik keadaan 
ekonominya. Engene Stanley dalam Sukamdiyo (1996), menyatakan bahwa pembangunan yang dapat diharapkan berhasil adalah pembangunan yang menjamin perkembangan demokrasi. Demokrasi berarti bahwa setiap orang merasa bertanggung jawab untuk ikut mengambil keputusan yang bermanfaat selain untuk dirinya juga untuk masyarakat secara keseluruhan.

Kecamatan Manonjaya merupakan salah satu kecamatan yang berada di Kabupaten Tasikmalaya Provinsi Jawa Barat. Kecamatan Manonjaya terdiri atas 11 desa dengan luas wilayah $44,71 \mathrm{~km}^{2}$ dan jumlah penduduk 60.952 orang (BPS Kabupaten Tasikmalaya, 2013). Daerah ini merupakan daerah agraris dan mempunyai potensi pengembangan di sektor pertanian yaitu usahatani padi sawah dan mendong, perikanan dan peternakan baik unggas, ternak kecil maupun ternak besar. Kegiatan bisnis yang banyak dilakukan adalah industri kreatif yang berbahan baku mendong.

Salah satu dampak dari pengusahaan lahan sempit adalah rendahnya pendapatan petani yang berdampak pula terhadap ketahanan pangan keluarga, yaitu rendahnya aksesibilitas keluarga tani dalam memperoleh kebutuhan terhadap pangan khususnya beras. Masyarakat petani yang miskin, selain luas lahannya yang sempit, juga disebabkan oleh produktivitas yang rendah, infrastruktur terbatas, aksesibilitas rendah terhadap modal, teknologi informasi dan pasar serta rendahnya kapasitas petani.

Peran kelembagaan agribisnis sangat menentukan terhadap keberhasilan pembangunan pertanian, karena diharapkan akan mampu berkontribusi terhadap aksesibilitas petani terhadap pengembangan sosial ekonomi petani, serta pasar.

Jika dikaitkan dengan sistem agribisnis, kelembagaan termasuk subsistem jasa penunjang dimana lembaga tersebut harus mampu berperan dalam menunjang terhadap kegiatan dalam subsistem pengadaan sarana produksi, usahatani, pengolahan hasil pertanian dan pemasaran. Petani sebagai pelaku utama adalah subjek dalam pembangunan agribisnis tersebut yang merupakan konsumen dari jasa yang diberikan oleh lembaga penunjang agribisnis tersebut. Agribisnis akan berjalan dengan baik jika tidak terjadi kesenjangan antara lembaga penunjang dengan kegiatan usahanya.

Berdasarkan uraian yang di atas, maka tujuan dari penelitian ini adalah 
untuk: (1) Mengidentifikasi kelembagaan agribisnis yang berperan dalam usahatani mendong, (2) Mengetahui tingkat kinerja kelembagaan agribisnis dalam usahatani mendong, dan (3) Mengetahui tingkat kepuasan petani terhadap kinerja kelembagaan agribisnis dalam usahatani mendong.

\section{TINJAUAN PUSTAKA}

Pembangunan pertanian tidak dapat terlaksana hanya oleh kegiatan para petani sendiri, dan untuk merubah bentuk pertanian dari yang bersifat subsisten atau untuk pemenuhan sendiri menjadi bentuk usahatani yang komersial sangat tergantung kepada sumber-sumber yang ada di luar lingkungan usahataninya. Mosher (1981), menyatakan bahwa terdapat dua syarat dalam pembangunan pertanian, yaitu: (1) Syarat mutlak, meliputi pasar untuk hasil pertanian, teknologi yang terus berkembang, tersedianya bahan-bahan produksi dan peralatan secara lokal, perangsang produksi bagi petani, serta pengangkutan. (2) Syarat pelancar, meliputi pendidikan pembangunan, kredit produksi, kegiatan gotong royong, perbaikan dan perluasan tanah/lahan pertanian serta perencanaan nasional untuk pembangunan pertanian.
Agribisnis merupakan cara pandang baru dalam melihat pertanian. Ini berarti bahwa pertanian tidak hanya on-farm activities, tetapi juga off-farm activities. Dengan demikian pertanian tidak hanya berorientasi produksi, tetapi juga berorientasi pasar, tidak hanya dilihat dari sisi permintaan (demand side) tetapi juga dari sisi penawaran (supply side). Dalam hal ini pertanian tidak hanya bercocok tanam, beternak, menambak ikan, dan berkebun saja; tetapi juga bagaimana memproses dan memasarkan outputnya, serta bagaimana keterlibatan penunjang (Saragih, 2010).

Pembangunan kelembagaan pertanian sebagai penujang keberhasilan agribisnis diperlukan karena: (1) Proses pertanian memerlukan sumberdaya tangguh yang didukung oleh infrastruktur, peralatan dan kredit, (2) Pembangunan kelembagaan petani lebih rumit daripada manajemen sumberdaya alam karena memerlukan faktor pendukung dan unit-unit produksi, (3) Kegiatan pertanian mencakup rangkaian penyiapan input, mengubah input menjadi produk dengan tenaga kerja dan manajemen dan menempatkan output menjadi lebih berharga, (4) Kegiatan pertanian memerlukan dukungan dalam bentuk kebijakan dan kelembagaan dari 
pusat dan lokal, (5) Kompleksitas pertanian yang meliputi unit usaha dan kelembagaan sulit mencapai optimal.

Suatu lembaga dibentuk untuk memenuhi kebutuhan manusia sehingga lembaga mempunyai fungsi, selain itu lembaga merupakan suatu konsep yang terpadu dengan struktur, artinya tidak saja melibatkan pola aktivitas yang lahir dari segi sosial untuk memenuhi kebutuhan manusia tetapi juga pola organisasi untuk melaksanakannya.

Roucek dan Warren (1994) dalam Anantayu (2011), menyatakan bahwa strategi-strategi yang dilakukan untuk memenangkan persaingan banyak sekali, salah satunya adalah dengan cara menyampaikan secara konsisten layanan yang berkualitas tinggi dibandingkan para pesaing dan lebih tinggi dari harapan pelanggan. Lebih lanjut Kotler (1997) menyatakan bahwa konsumen akan merasa puas bilamana produk atau jasa yang dirasakan memiliki kualitas yang sesuai dengan harapan.

Kepuasan konsumen menurut Kotler (1997) merupakan fungsi kedekatan antara harapan/ekspektasi konsumen dengan prestasi produk yang dirasakan konsumen (perceived performance). Tingkat kepuasan dapat dijadikan sebagai tolak ukur keberhasilan dan selanjutnya dapat digunakan dalam pengembangan usaha.

Umar (2005) menyatakan bahwa kepuasan konsumen akan terpenuhi apabila proses penyampaian jasa dari si pemberi jasa kepada konsumen sesuai dengan apa yang dipersepsikan oleh konsumen. Perbedaan cara penyampaian dari apa yang dipersepsikan konsumen itu mencakup 5 gap:

1) Gap antara harapan konsumen dan persepsi manajemen.

2) Gap antara persepsi manajemen tentang harapan konsumen dan spesifikasi kualitas jasa.

3) Gap antara spesifikasi kualitas jasa dan jasa yang disajikan.

4) Gap antara penyampaian jasa aktual dan komunikasi eksternal kepada konsumen.

5) Gap antara jasa yang diharapkan dan jasa aktual yang diterima konsumen.

Beberapa hasil penelitian tetang kelembagaan agribisnis diantaranya Juraemi (2004) yang menyatakan bahwa terdapat empat kelembagaan yang mendukung dalam keragaan sistem agribisnis kelapa sawit, yaitu kelompok tani, koperasi, PPL perkebunan serta pembina perkebunan. Anantanyu (2011) menyimpulkan hasil penelitiannya bahwa peningkatan kapasitas 
kelembagaan petani dilakukan sejalan dengan kegiatan penyuluhan pertanian dengan memotivasi petani untuk berpartisipasi dalam kelembagaan petani, dengan memberikan muatan pada penguatan kapasitas individu petani sekaligus kapasitas kelembagaan petani. Tedjaningsih, dkk. (2016) menyimpulkan bahwa masih diperlukan pembinaan terhadap petani baik secara individu maupun kelembagaan untuk mendorong petani menggunakan pupuk organik pada usatani mendong.

\section{METODE PENELITIAN}

Pelaksanaan penelitian ini menggunakan metode survei, pengambilan sampel menggunakan simple random sampling terhadap petani mendong di Kecamatan Manonjaya dengan jumlah sampel sebanyak 25 orang.

Data yang diperoleh dianalisis secara deskriptif kualitatif dan kuantitatif. Untuk mengetahui tanggapan petani terhadap pelayanan fungsi kelembagaan agribisnis digunakan Importance Performance Analysis (IPA) atau Analisis Tingkat Kepentingan dan Kinerja/Kepuasan Pelanggan (John dan James dalam Supranto, 2006), dan digambarkan dalam diagram Kartesius.
Kepuasan petani terhadap kinerjanya digunakan Consumer Satisfaction Index (Aritonang, 2005).

IPA atau Analisis Tingkat Kepentingan dan Kinerja terdiri atas dua komponen, yaitu analisis kuadran dan analisis kesenjangan:

a. Menghitung rata-rata penilaian kepentingan dan kinerja untuk setiap atribut:

$$
\overline{X i}=\frac{\sum_{i=1}^{k} X i}{n} \leftrightarrow \overline{Y i}=\frac{\sum_{i=i}^{k} Y i}{n}
$$

$\overline{X i}=$ bobot rata-rata tingkat penilaian kinerja atribut ke-i

$\overline{Y i}=$ bobot rata-rata tingkat penilaian kepentingan atribut ke-i

$\mathrm{n}=$ jumlah responden

b. Menghitung rata-rata tingkat kepentingan dan kinerja untuk keseluruhan atribut

$$
\overline{\overline{X i}}=\frac{\sum_{i=1}^{k} \overline{X i}}{n} \leftrightarrow \overline{\overline{Y i}}=\frac{\sum_{i=1}^{k} \overline{Y i}}{n}
$$

$$
\begin{aligned}
& \overline{\overline{X i}}=\text { nilai rata-rata kinerja atribut } \\
& \overline{\overline{Y i}}=\text { nilai rata-rata kepentingan atribut } \\
& \mathrm{n}=\text { jumlah atribut }
\end{aligned}
$$

Setelah diperoleh bobot kinerja dan kepentingan serta nilai rata-rata kinerja dan kepentingan, kemudian diplotkan ke dalam diagram Kartesius seperti tersaji pada Gambar 1. 
Kepentingan

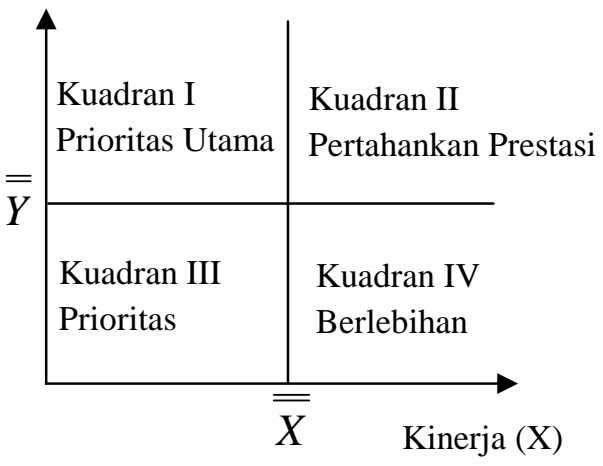

\section{Gambar 1. Diagram Kartesius}

Consumer Satisfaction Index (CSI) digunakan untuk mengetahui tingkat kepuasan petani terhadap kelembagaan agribisnis secara menyeluruh dengan melihat tingkat kepentingan dari masingmasing unsur:

a. Menentukan Mean Importance Score (MIS)

$$
\text { MIS }=\frac{\sum_{i=1}^{n} Y i}{n}
$$

$\mathrm{n}=$ jumlah responden

$\mathrm{Yi}=$ Nilai kepentingan atribut $\mathrm{Y}$ ke-i

b. Menentukan Mean Satisfaction Score (MSS)

$$
\mathrm{MSS}=\frac{\sum_{i=1}^{n} X i}{n}
$$

$\mathrm{n}=$ jumlah responden

$\mathrm{Xi}=$ Nilai kepentingan atribut $\mathrm{X}$ ke $-\mathrm{i}$

c. Membuat Weight Factors (WF)

$$
\mathrm{WF}=\frac{M I S i}{\sum_{i=1}^{i} M I S i} \times 100 \%
$$

d. Membuat Weight Score (WS)

$$
\mathrm{WSi}=\mathrm{WFi} \times \mathrm{MSS}
$$

e. Menentukan Customer Satisfaction Index (CSI)

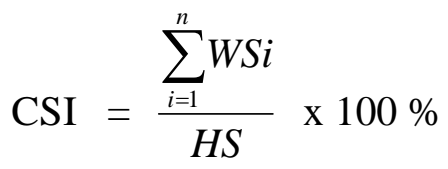

$\mathrm{i}=$ atribut kepentingan $\mathrm{ke}-\mathrm{i}$

$\mathrm{HS}=($ Highest scale) skala maksimum yang digunakan

Pada umumnya, nilai CSI di atas 50\% dapat dikatakan bahwa konsumen sudah merasa puas, tetapi bila nilai CSI di bawah 50\% dapat dikatakan bahwa konsumen belum puas.

\section{Tabel 1. Kriteria Indeks Kepuasan} Pelanggan ( CSI )

\begin{tabular}{ccl}
\hline No & Nilai CSI & Kriteria CSI \\
\hline 1 & $0,81-1,00$ & Sangat puas \\
\hline 2 & $0,66-0,80$ & Puas \\
\hline 3 & $0,51-0,65$ & Cukup puas \\
\hline 4 & $0,35-0,50$ & Kurang puas \\
\hline 5 & $0,00-0,34$ & Tidak puas \\
\hline
\end{tabular}

\section{HASIL DAN PEMBAHASAN}

Pada umumnya responden sudah berusahatani mendong lebih dari separuh usianya sehingga usahatani mendong sudah menjadi way of life.

Selain berusahatani padi dan mendong, ada juga responden yang mempunyai pekerjaan lain seperti buruh, pedagang dan pengrajin mendong. Luas lahan garapan mendong yang diusahakan 
oleh responden berkisar rata-rata 0,25 ha. dengan status penguasaan lahan adalah pemilik penggarap, penyakap, sewa dan nengah.

\section{Sistem Agribisnis Mendong}

Petani sebagai salah satu pelaku dalam industri permendongan yang menghasilkan produk pertanian primer /mendong keberhasilannya tidak akan terlepas dari subsistem lainnya dari hulu sampai hilir yang terintegrasi dalam sistem agribisnis mending sebagaimana terlihat pada Gambar 2.

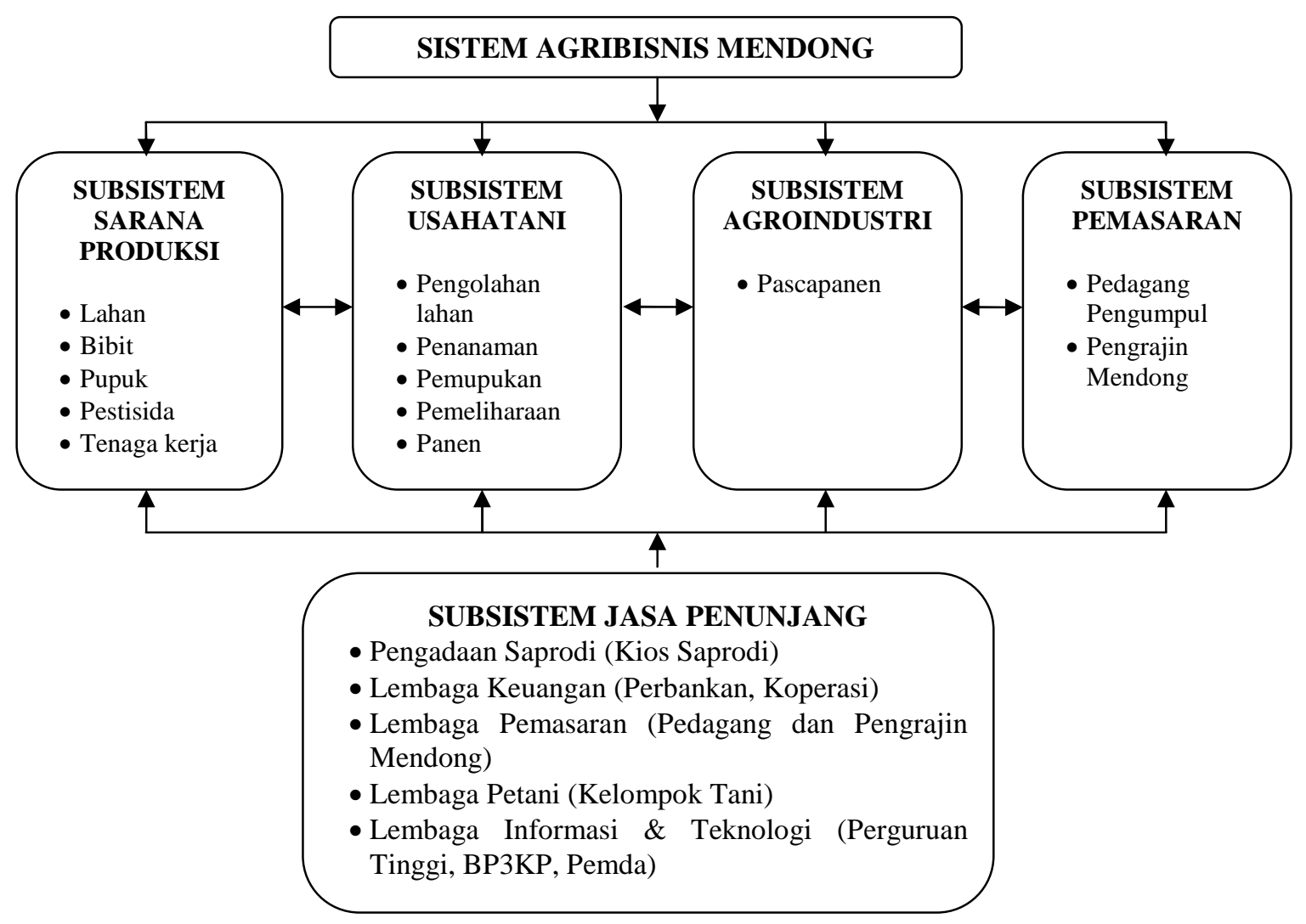

Gambar 2. Sistem Agribisnis Mendong

Subsistem Pengadaan dan Penyaluran Sarana Produksi

Usahatani mendong yang dilakukan oleh petani menggunakan lahan sawah beririgasi teknis dari sungai Cimulu. Usahatani yang dilakukan pada umumnya monokultur akan tetapi karena sistem pengairan yang bagus ada juga yang mengusahakan dengan sistem mina mendong.

Sempitnya penguasaan lahan menyebabkan petani enggan untuk mengambil risiko jika harus menerapkan 
teknologi baru. Introduksi penggunaan pupuk organik juga sudah dilakukan. Hasil penelitian Tedjaningsih dan Suyudi (2016) menunjukkan bahwa penggunaan pupuk organik pada beberapa petani hanya pada saat tidak terdapat atau susah diperolehnya pupuk anorganik.

Keunggulan mendong adalah sekali tanam dapat dipanen berkali-kali sehingga dibandingkan dengan tanaman semusim lainnya tanaman mendong merupakan tanaman yang mempunyai nilai ekonomis tinggi (Sunanto, 2004).

Sarana produksi pada agribisnis mendong meliputi input yang terdiri atas bibit mendong, pupuk urea, phonska dan pupuk organik serta obat-obatan, Introduksi penggunaan pupuk organik juga sudah dilakukan. Penggunaan bibit rata-rata 1.111 batang/ha, Urea $100 \mathrm{~kg} / \mathrm{ha}$. Phonska $300 \mathrm{~kg} / \mathrm{ha}$. Penggunaan pupuk Phonska ini mampu mengurangi penggunaan pupuk urea karena pupuk ini sudah mengandung unsur hara nitrogen, phospor dan kalium sekaligus.

Pada umunya petani mendapatkan sarana produksi berupa pupuk dan obatobatan dari kios atau warung saprotan yang berada di wilayahnya, sedangkan bibit mendong diperoleh dari sesama petani. Pupuk organik ada yang dibeli dari kios saprodi ada pula yang membuat sendiri terutama para petani yang mempunyai ternak domba, kambing dan sapi.

Cara perolehan sarana produksi tersebut dengan pembelian secara tunai. Kesulitan yang dialami oleh petani dalam pengadaan sarana produksi ini adalah pada saat langkanya sarana produksi sehingga sulit diperoleh yang menyebabkan harga menjadi lebih tinggi, artinya petani harus mempunyai modal secara tunai yang lebih besar. Untuk mengatasi kekurangan modal, petani pada umumnya lebih mengandalkan meminjam kepada saudara atau tetangga dibandingkan kepada lembaga keuangan koperasi atau perbankan.

Tenaga kerja yang digunakan untuk usahatani mendong adalah tenaga kerja dalam keluarga dan tenaga kerja luar keluarga yang berasal dari warga setempat. Penggunaan tenaga kerja yang lebih banyak untuk kegiatan pemeliharaan dibandingkan dengan kegiatan pengolahan tanah, panen dan pasca panen, karena pemeliharaan termasuk kegiatan pemupukan dan penyiangan

\section{Subsistem Usahatani}

Pelaku dalam produksi mendong adalah anggota kelompok tani yang ada di Kecamatan Manonjaya, namun kelompok tersebut bukan kelompok untuk petani 
mendong karena kelompok tersebut juga merupakan kelompok untuk petani padi.

Mendong merupakan salah satu komoditas perkebunan, akan tetapi sama halnya dengan usahatani tanaman pangan padi, masih merupakan skala usahatani kecil dengan luas lahan usaha antara 0,04 ha sampai dengan 0,57 ha.

Pengolahan dilakukan dengan cara dicangkul yang tujuannya untuk membalikan dan meratakan tanah serta membuat selokan untuk jalan air. Tenaga kerja yang digunakan adalah tenaga kerja dalam dan luar keluarga

Bibit mendong yang digunakan adalah bibit unggul yang siap tanam. Ukuran bibit adalah yang masih mempunyai ketinggian sekitar $20 \mathrm{~cm}$. Penanaman mending pun menggunakan jarak tanam, yang biasa digunakan adalah jarak tanam $30 \mathrm{~cm}$ x $30 \mathrm{~cm}$. Tujuan dari penggunaan jarak tanak adalah untuk memudahkan dalam pemeliharaan, apalagi jika diusahakan bersama-sama budidaya ikan atau mina mendong.

Pemupukan pada tanaman mendong dilakukan tiga kali, yaitu pemupukan dasar pada saat pengolahan lahan dengan menggunakan pupuk kandang, kemudian dilanjutkan dengan pemupukan susulan pada umur 45 hari setelah tanam (HST) dan umur 75 HST masing-masing 50 kg urea dan $150 \mathrm{~kg}$ phonska untuk setiap kali pemupukan

Pemeliharaan tanaman mendong yang dilakukan berupa penyiangan gulma yang berada pada areal pertanaman, pemeliharaan saluran air atau penyemprotan pestisida jika terserang hama atau penyakit. Pemeliharaan saluran air diperlukan karena pada fase-fase tertentu mendong memerlukan kecukupan air.

Tanaman mendong termasuk tanaman musiman, rata-rata dapat dipanen 8-10 kali. Panen dilakukan setelah tanaman berumur 3-4 bulan dengan cara menyabit rumpun mendong dan menyisakan kurang lebih 1-2 cm dari permukaan tanah, sehingga akan muncul kembali tunas sehingga bertambah jumlah anakan mendong dan kembali dapat dipanen setelah berumur 3-4 bulan. Sehingga pada usahatani mendong pengadaan bibit hanya dilakukan satu kali selama satu periode, yaitu sekitar 2,5 tahun.

Hasil produksi mendong rata-rata sekitar 4,255 ton mendong kering per ha atau 6-7 $\mathrm{kg}$ mendong kering per bata. Peningkatan produksi dan produktivitas terus dilakukan dengan dilakukan dilakukannya penelitian dan sosialisasi dan pelatihan teknologi budidaya baik 
oleh perguruan tinggi khususnya Universitas Siliwangl maupun oleh pemerintah daerah melalui Dinas Pertanian.

\section{Subsistem Pengolahan Hasil Pertanian (Agroindustri)}

Pasca panen yang dilakukan oleh petani adalah dengan menjemur mendong yang telah diarit di atas tanah sampai kering. Untuk menghindari kebusukan jika dipanen pada saat hujan, maka pada saat penjemuran ditaburi abu sekam padi, kemudian diikat masing-masing sekitar $30-40 \mathrm{~kg}$.

Setelah kering benar maka dilakukan grading berdasarkan panjang batang mending. Sortir dilakukan dengan mencabut (mautan) batang mendong yang ukurannya berbeda untuk disatukan dengan ukuran panjang yang sama. Ukuran panjang mendong adalah $70 \mathrm{~cm}$, $80 \mathrm{~cm}, 90 \mathrm{~cm} \mathrm{~cm}, 100 \mathrm{~cm}$ dan $120 \mathrm{~cm}$. Ukuran yang panjang biasanya digunakan untuk bahan baku tikar mending, sedangkan ukuran pendek digunakan sebagai bahan kerajinan lainnya seperti sajadah, taplak meja, dompet, sandal dan kipas.

Suyudi, dkk. (2015) telah mensosialisasikan penggunaan bahan pengawet alami untuk mempertahankan kualitas mendong serta alat pengering bagi para pengrajin mendong, akan tetapi masih belum terlihat nyata responnya karena ada keterkaitannya dengan keterbatasan dalam pengadaan bahan pengawet.

\section{Subsistem Pemasaran Hasil Pertanian}

Petani menjual mendong kering kepada pedagang, pengumpul/bandar atau langsung kepada pengrajin mendong. Akhir-akhir ini terjadi kesulitan dalam penjualan mendong karena pedagang pengumpul/bandar membatasi pembelian mendong sebab banyak perusahaan pengrajin tikar yang mengurangi bahan baku dari mendong dan beralih menggunakan bahan baku mendong plastik. Hal tersebut berakibat pada menurunnya pendapatan petani.

\section{Kepentingan dan Kinerja Kelembagaan Agribisnis Mendong}

Tingkat kepentingan merupakan tingkat harapan petani terhadap pelayanan yang diberikan oleh kelembagaan agribisnis. Semakin tinggi tingkat harapan petani terhadap pelayanan kelembagaan agribisnis, maka semakin penting pula pelayanan fungsi kelembagaan tersebut untuk dilaksanakan melalui kinerjanya.

Atribut yang menjadi penilaian petani terhadap 5 fungsi pelayanan 
kelembagaan agribisnis mendong terdiri atas 23 atribut.

Tabel 2 memperlihatkan bahwa 60,87 persen atau 14 dari 23 atribut pelayanan kelembagaan agribisnis sangat penting, artinya bahwa responden sangat berharap kelembagaan agribisnis tersebut sangat penting untuk dapat dilaksanakan. 8 atribut 34,78 persen dianggap penting agar dapat membantu dalam kegiatan usahatani mendongnya.

Tabel 2. Kategori dan Kesesuaian Kinerja dengan Kepentingan

\begin{tabular}{|c|c|c|c|}
\hline \multirow{2}{*}{ Atribut Kelembagaan Agribisnis } & \multicolumn{2}{|c|}{ Katagori } & \multirow{2}{*}{$\begin{array}{l}\text { Kesesuaian } \\
\quad(\%)\end{array}$} \\
\hline & Kepentingan & Kinerja & \\
\hline \multicolumn{4}{|l|}{ I. Kelembagaan Pengadaan Sarana Produksi } \\
\hline 1. Kelengkapan saprodi & SP & $\mathrm{B}$ & 91.09 \\
\hline 2. Kualitas Saprodi & SP & $\mathrm{B}$ & 89.80 \\
\hline 3. Cara pembayaran & SP & $\mathrm{B}$ & 87.88 \\
\hline 4. Ketersediaan & SP & $\mathrm{B}$ & 78.22 \\
\hline 5. Harga saprodi & SP & $\mathrm{CB}$ & 70.65 \\
\hline \multicolumn{4}{|l|}{ II. Kelembagaan Pembiayaan } \\
\hline 6. Keberadaan koperasi & SP & $\mathrm{CB}$ & 61.00 \\
\hline 7. Keberadaan Bank & $\mathrm{P}$ & $\mathrm{CB}$ & 83.33 \\
\hline 8. Persyaratan kredit & $\mathrm{P}$ & $\mathrm{B}$ & 91.31 \\
\hline 9. Tingkat $\mathrm{k}$ suku bunga & $\mathrm{CP}$ & $\mathrm{CB}$ & 104.48 \\
\hline \multicolumn{4}{|l|}{ III. Kelembagaan Pemasaran } \\
\hline 10. Syarat Pembelian & SP & $\mathrm{CB}$ & 73.33 \\
\hline 11. Harga Jual mendong & SP & $\mathrm{CB}$ & 73.78 \\
\hline 12. Cara pembayaran & SP & $\mathrm{B}$ & 94.85 \\
\hline 13. Kemampuan membeli & $\mathrm{P}$ & $\mathrm{B}$ & 86.32 \\
\hline \multicolumn{4}{|l|}{ IV. Kelembagaan Kelompok Tani } \\
\hline 14. $\quad$ Koord program & SP & $\mathrm{CB}$ & 78.79 \\
\hline 15. Tempat diskusi & SP & $\mathrm{B}$ & 74.77 \\
\hline 16. Tempat produksi & SP & $\mathrm{CB}$ & 73.47 \\
\hline 17. $\quad$ Penyedia saprodi & SP & $\mathrm{CB}$ & 73.53 \\
\hline 18. Koperasi kelompok tani & SP & $\mathrm{CB}$ & 79.78 \\
\hline 19. Tempat belajar & $\mathrm{P}$ & $\mathrm{CB}$ & 82.98 \\
\hline \multicolumn{4}{|l|}{ V. Kelembagaan Informasi dan teknologi } \\
\hline 20. Sosialisasi Inovasi & $\mathrm{P}$ & $\mathrm{B}$ & 84.37 \\
\hline $\begin{array}{l}\text { 21. Menerima aspirasi dan mencari } \\
\text { solusi }\end{array}$ & $\mathrm{P}$ & $\mathrm{CB}$ & 85.71 \\
\hline 22. Fasilitas kerjasama & $\mathrm{P}$ & $\mathrm{CB}$ & 87.06 \\
\hline 23. Tempat pelatihan & SP & $\mathrm{CB}$ & 91.09 \\
\hline Rata-rata & $\mathrm{P}$ & $\mathrm{CB}$ & 81,62 \\
\hline
\end{tabular}

Keterangan:

Sangat penting (SP) / Sangat baik (SB)

Penting (P) / Baik (B)

Cukup penting (CP) / Cukup baik (CB)

Kurang penting (KP) / Kurang baik (KB)

Tidak penting (TP) / Tidak baik (TB) 
Tingkat suku bunga mempunyai kesesuaian lebih dari 100 persen. Responden mengetahui bahwa untuk kegiatan usahatani sebenarnya ada bantuan pinjaman dengan tingkat suku bunga rendah, sehingga responden menganggap bahwa lembaga keuangan tersebut sudah cukup baik dalam melaksanakan fungsinya, akan tetapi responden sampai saat ini masih merasa belum membutuhkan pinjaman dari lembaga pembiayaan formal karena petani pada umumnya melaksanakan kegiatan usahatani sesuai dengan kemampuan keuangannya.

Kinerja adalah pelaksanaan pelayanan kelembagaan agribisnis dalam menjalankan fungsinya. Atribut fungsi pelayanan baru 9 atau 39,13 persen yang dilaksanakan dengan baik.

Jika melihat Tabel 2 di atas, ratarata tingkat kesesuaian 81,62 persen, yang tertinggi adalah cara pembayaran yang dilakukan oleh pedagang pengumpul atau bandar yang melakukan pembelian mendong yaitu 94,85 persen, artinya cara pembayaran sudah sesuai dengan yang diharapkan responden yaitu pembayaran tunai. Sehingga dapat segera memenuhi kebutuhan hidupnya serta membiayai kegiatan usahataninya.

\section{Importance Performance Analysis (IPA)}

Kinerja kelembagaan dianalisis dengan menggunakan Metode Importance and Performance Analisys (IPA) yang berkaitan dengan kepentingan apa yang diharapkan petani terhadap kelembagaan yang mendukung usaha mereka serta kinerja yang telah dilakukan oleh kelembagaan tersebut yang telah dirasakan oleh para petani. 


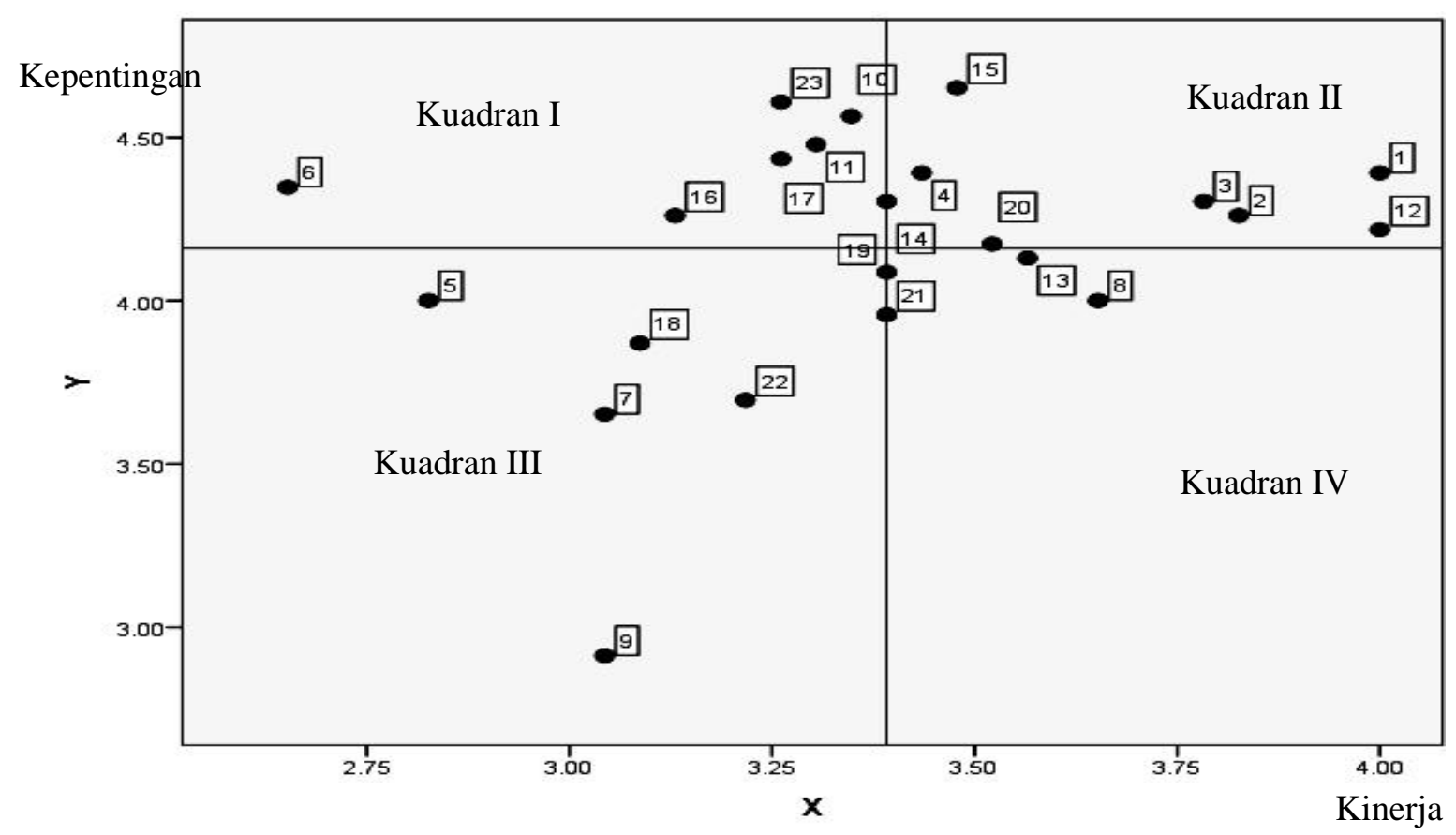

Gambar 3. Diagram Kartesius Kelembagaan Agribisnis Mendong

Keterangan:

1. Kelengkapan saprodi

2. Kualitas Saprodi

3. Cara pembayaran

4. Ketersediaan

5. Harga saprodi

6. Keberadaan koperasi

7. Keberadaan bank

8. Persyaratan kredit

9. Tingkat suku bunga

10. Syarat pembelian

11. Harga jual mendong

12. Cara pembayaran

\section{1) Kuadran I Prioritas Utama}

Kuadran I menunjukkan kepentingan petani terhadap pelayanan fungsi kelembagaan agribisnis atau penting dengan skor di atas rata-rata (> 4,1607) akan tetapi kinerjanya masih kurang dengan skor di bawah rata-rata $(<$ 3,374) sehingga atribut-atribut pelayanan
13. Kemampuan membeli

14. Koordinasi program

15. Tempat diskusi

16. Tempat produksi

17. Penyedia saprodi

18. Koperasi kelompok tani

19. Tempat belajar

20. Sosialisasi inovasi

21. Menerima aspirasi dan mencari solusi

22. Fasilitas kerjasama

23. Tempat pelatihan

tersebut harus menjadi prioritas kerja kelembagaan agribisnis mendong.

Harga jual yang diterima oleh responden atau harga beli oleh pedagang penting, karena responden pada umumnya hanya mengandalkan penerimaannya dari mendong hasil panennya. Harga mendong penting bagi responden apalagi pada masa sekarang ini persaingan mendong sebagai 
bahan baku industri kerajinan tersaingi oleh bahan sintetis yang diimpor dari luar dengan harga yang relatif lebih murah yang pengadaannya tidak terkendala waktu.

Keberadaan kelompok tani sebagai unit/tempat produksi dirasakan oleh responden penting. Adanya kelompok sebagai tempat produksi menurut responden sangat membantu perekonomian keluarga, karena dapat menambah penghasilan keluarga dengan mempekerjakan anggota keluarga kelompok tani tersebut.

\section{2) Kuadran II Pertahankan Prestasi}

Kuadran II menunjukkan kepentingan petani terhadap pelayanan fungsi kelembagaan agribisnis penting dengan skor di atas rata-rata $(>4,1607)$ dengan kinerjanya sudah baik dengan skor di atas rata-rata (> 3,3743) sehingga atribut-atribut pelayanan tersebut harus tetap diperhatikan.

\section{3) Kuadran III Prioritas Rendah}

Kuadran III menunjukkan kepentingan petani terhadap pelayanan fungsi kelembagaan agribisnis mempunyai kedudukan kurang penting dengan skor di bawah rata-rata

4,1607) dengan kinerjanya kurang dengan skor di bawah rata-rata $(<3,3743)$ sehingga atribut-atribut pelayanan tersebut tidak menjadi prioritas dalam pelaksanaannya

Atribut-atribut pada kuadran ini bukan berarti tidak perlu untuk menjadi perhatian terutama pada harga sarana produksi. Harga sarana produksi berapa pun akan dibeli oleh responden untuk keperluan usahataninya selama ketersediaan sesuai dengan kualitasnya yang merupakan atribut pelayanan dari kelembagaan pengadaan sarana produksi yang harus dipertahankan kinerjanya serta diimbangi oleh nilai tukar mendong yang baik dan menguntungkan yang menjadi prioritas utama.

\section{4) Kuadran IV Berlebihan}

Merupakan kuadran dengan atribut pelayanan yang berlebihan yang mempunyai kedudukan penting dengan skor di bawah rata -rata $(<4,1607)$ dan telah dilaksanakan cukup baik dengan skor di atas rata-rata $(>3,3743)$.

Atribut-atribut tersebut pada saat ini dirasakan sudah cukup baik dalam pelaksanaannya terutama dalam kemampuan membeli mendong dari petani dari kelembagaan pemasaran yaitu pedagang pengumpul atau bandar dan pengrajin, akan tetapi dengan adanya bahan subsitusi dari mendong untuk bahan baku tikar, kerajinan anyaman 
(craft) akan berdampak kepada daya tampung dan permintaan yang dimiliki oleh para pedagang tersebut.

\section{Customer Satisfaction Index (CSI)}

Tingkat kepuasan petani secara keseluruhan diukur dengan menggunakan alat analisis Customer Satisfaction Index (CSI). Tingkat kepuasan ini dihitung berdasarkan nilai rata-rata total dari tingkat kepentingan dan tingkat kinerja dari kelembagaan agribisnis.

Berdasarkan hasil perhitungan diperoleh hasil CSI untuk atribut kinerja kelembagaan agribisnis mendong pada usahatani mendong sebesar 67,66 persen atau 0,6766. Nilai tersebut jika berdasarkan Indeks Kepuasan Pelanggan yang biasa digunakan oleh PT Sucofindo berada pada kisaran $0,66-0,80$ termasuk dalam kriteria puas.

Angka tersebut mengidentifikasikan bahwa secara umum petani mendong telah merasa puas terhadap kinerja kelembagaan agribisnis yang berada di Kecamatan Manonjaya karena secara keseluruhan fungsi kelembagaan agribisnis tersebut telah mampu memenuhi harapannya.

\section{PENUTUP}

Kios sarana produksi, pedagang pengumpul/bandar, pengrajin, kelompok tani, penyuluh dan perguruan tinggi adalah lembaga agribinis yang telah mampu berperan dalam menjalankan fungsi kelembagaan agribisnis pada usahatani mendong.

Kelembagaan agribisnis telah menjalankan kinerjanya dengan cukup baik dengan prioritas peningkatan fungsi kelembagaan pada keberadaan koperasi, persyaratan pembelian mendong, harga jual mendong, kelompok tani sebagai unit produksi dan penyedia sarana produksi serta pelatihan oleh lembaga informasi dan inovasi.

Tingkat kepuasan petani terhadap pelayanan fungsi kelembagaan berada pada kategori puas.

Kelembagaan agribisnis masih perlu ditingkatkan lagi karena meskipun telah masuk dalam kategori puas, jika dilihat dari indeks kepuasaannya masih berada pada batas minimal. Untuk meningkatkan kinerja dari fungsi kelembagaan agribisnis agar mampu menghadapi tantangan persaingan maka perlu adanya penguatan kemandirian petani yaitu peningkatan fungsi kelompok tani sebagai unit produksi dan pengadaan sarana produksi sehingga ada peningkatan nilai tambah dan nilai tukar dari kegiatan usahataninya dengan tidak terlepas dari adanya 
pelatihan penerapan inovasi teknologi dari lembaga terkait.

\section{DAFTAR PUSTAKA}

Anantanyu, S. 2011. Kelembagaan Petani, Peran dan Strategi Pengembangan Kapasitasnya. Jurnal SEPA, 7(2): 102-109.

Aritonang, R.L. 2005. Kepuasan Pelanggan. Jakarta: PT Gramedia Pustaka Utama.

BPS Kabupaten Tasikmalaya. 2013. Kabupaten Tasikmalaya dalam Angka. Tasikmalaya.

Juraemi. 2004. Hubungan Antara Kinerja Kelembagaan dengan Keragaan Sistem Agribisnis pada Perusahaan Inti Rakyat Perkebunan Kelapa Sawit. Jurnal EPP, 1(2):33-40.

Kotler, P. 1997. Manajemen Pemasaran Analisis Perencanaan, Implementasi dan Pengendalian (terjemahan Jaka Wasana). Jakarta: PT Salemba Empat.

Mosher. A.T. 1981. Menggerakkan dan Membangun Pertanian. Jakarta: Yasaguna.

Oktaviani, R.W. dan Suryana, R.N. 2006. Analisis Kepuasan Pengunjung dan Pengembangan Fasilitas Wisata Agro (Studi Kasus di Kebun Wisata Pasirmukti Bogor. Jurnal Agro Ekonomi, 24(1): 41-58.

Saragih, B. 2010. Agribisnis, Paradigma Baru Pembangunan Ekonomi
Berbasis Pertanian. Jakarta: IPB Press.

Sukamdiyo, I. 1996. Manajemen Koperasi. Jakarta: Erlangga.

Sunanto, H. 2004. Budi Daya Mendong. Yogjakarta: Kanisius.

Supranto, J. 2006. Pengukuran Tingkat Kepuasan Pelanggan Untuk Menaikan Pangsa Pasar. Jakarta: PT Rineka Cipta.

Suyudi, Priatna, E. dan Tedjaningsih, T. 2015. Sosialisasi Penggunaan Pupuk Organik pada Tanaman Mendong di Kecamatan Manonjaya Kabupaten Tasikmalaya. Laporan IbM Tasikmalaya. LPPM Universitas Siliwangi.

Suyudi, Priatna, E. dan Tedjaningsih, T. 2016. Teknologi Penguat Bahan Baku Mendong Untuk Meningkatkan Pendapatan Pengrajin Mendong di Kecamatan Manonjaya Kabupaten Tasikmalaya. Jurnal Pengabdian Masyarakat Universitas Siliwangi Tasikmalaya, 1(1), Desember 2015.

Tedjaningsih, T., Suyudi dan Nuryaman, H. 2017. Persepsi Petani Terhadap Penggunaan Pupuk Organik Pada Usahatani Mendong. Mimbar Agribisnis: Jurnal Pemikiran Masyarakat Ilmiah Berwawasan Agribisnis, 3(1): 64-72.

Umar, H. 2005. Riset Pemasaran dan Perilaku Konsumen. Jakarta: PT Gramedia Pustaka Utama dengan Jakarta Business Research Centre. 